\title{
Managing Skills of the Education and Training Process of Higher Education Managers in Albanian Universities
}

\author{
Kseanela Sotirofski \\ University "A. Moisi", Faculty of Education \\ nelasotiri@yahoo.com
}

Doi:10.5901/ajis.2014.v3n4p499

\section{Abstract}

Universities are institutions of knowledge acquisition, storage and dissemination. The most important source of information age is information on the application and human benefit. Therefore, it must be appropriate for the age of the vision and work of university administrators. However, in recent years, university administrators, with regard to the qualifications required, they are selected according to criteria that do not serve directly to the university. Development and change at our age, so that we can come to a position of competing with the world conditions of university administrator, is an inevitable necessity. This research has been conducted by university administrators in Albania. It focuses on educational leadership roles they perform and their level of importance as it reveals the differences and similarities between these levels. At the same time, it relates to university administrators for both countries because it is a research on educational leadership in higher education and will provide an important resource for subsequent research. In this research, it is shed light on the acquisition of qualification required for Albanian higher education administrators. Additionally, this research, may contribute to the role of leadership by the higher education administrators for the developing higher education systems. At the end of this research about Albanian universities, the results will serve educational leadership and there will be a better diagnosis of the tasks arising from it. This may affect their quality variables. Moreover, it will have an impact on managerial decisions and is intended to enhance educational quality.

\section{Introduction}

Administrators who work in higher education institutions should be always sensitive to manage the teaching and learning process and to be an ispiration model of this process.

The network comprises university, local, regional, national and international, economic, social and cultural factors. They are part of a multi-party network and people's future prospects. At the same time, universities, organizations such as the Boton, and other institutions are faced with change from technological development. Universities should contribute to economic and social development of their region, to build international bridges, and benefit from students of different cultures. Institutions all over the world face these problems and it is in their interest to focus on developing their research and learning the outcomes. (Coaldrak, 2001: 3, 10).

Efficiency and efficacy of the university is a very urgent and leadership crisis, which is linked directly to lack in certain areas. One way out of this crisis is for magaers to develop new leadership skills (Paul and others, 1997: 327).

Discussion and research into the leadership role of managers continues for many years. Leadership overall building structure and purpose to achieve organizational goals or change is defined as the start or procedures. However, the definition of educational leadership's role of the manager is not completely clarified. This is beacuse educational leadership in educational institutions carries a different meaning from leadership roles in other fields. Having a unique style of leadership for the organization of educational leadership, due to the inherent characteristics of the organization. (King, 2002: 62).

Research on the academic leadership of the managers is usually carried out in relation to and often intertwined with effective research organizations (Wildly and Dimmock, 1993: 43).

In most of this research having a strong educational leader has emerged as one of the common characteristics of effective organizations. However, in educational leadership, it is not possible to mention a complete consensus about effectiveness. Effectiveness has been generally regarded as a multi-dimensional concept (Griffin, 1993: 20).

Studies on the efficiency and effectiveness have been carried out for a long time. This research reveals the most important elements of educational leadership effectiveness. However, the concept of managers of educational organizations and leadership role has undergone significant changes over the last 10-15 years. In the seventies and eighties of the first period, we look at the assignments to the students and this assignment relates to classic management 
process with planning, organizing, directing and controlling. It is about traditional management functions related to them. However, today educational leaders add new elements to the assignment (mcev, 1994: 5) .

Greenfield, who works in the field of educational leadership (1987) views managers as educational leaders, but he has not yet created a guide that provides an image that has been put forward by the practitioners.

However, the debate on the meaning of the term has not been completed by researchers. Despite the failure to come to an agreement on this issue, the concept of educational leadership is increasingly encountered in the studies. (Deal, 1987: 243).

In parallel with this development, the number of managerial activities are numerous (Griffin, 1993: 33). The examination of this event, overall training program of instructional leadership, a leadership approach is understood to be giving more priority to academic achievement and teaching issues. Effective managers usually know the problems of teaching environment and determine educational goals and objectives (Griffin, 1993: 35). These leaders also attach importance to high academic standards and the supervision of their lecturers and evaluation. In addition, they plan their teaching programs and evaluate and create a positive atmosphere for learning (Brookover and Others, 1977: 18; Hallinger and Murphy, 1985: 220).

Studies conducted on leadership in educational organizations, effective institutions and effective leaders often indicate those managed by educational leaders (Gumusel, 1996: 13; Balci, 2001: 127). An educational leader is seen as a key factor in being source of inspiration to the effectiveness of the institution (Kruger, 1992: 435). Among the characteristics of successful organizations there is a clear organizational mission who draws attention to learning and the learning facilitator has been identified as an important element for educational leaders to create a school climate (Hallinger and Others, 1989: 9).

One of the purposes of the higher education institutions is to educate students according to their educational objectives. Students will be educated and trained according to the program of the educational institution. The means to manage the educational institutions are actually managing training programs and teaching (Basaran, 1994: 81). However, the managers of educational institutions today are most of the time devoted to administrative work. Although the roles of administrators as educational leaders are important, they rarely perform them Ozden (1998: 132). Today, higher education managers, instead of teaching activities, they focus on contracting type of activities.

Education teaching resources and training required by the executive leadership include work-related training programs and teaching. This dimension consists of several interrelated aspects. They monitor and evaluate teaching, monitor student progress, and coordinate training programs (Barrinea, 2001).

The main task of the managers of educational institutions is to ensure the transformation of educational practices of the organization's objectives. This task, of course instructors' goals with organizational goals coordinated upgrade, maintain and support from them requires monitoring the classroom teaching through informal classroom visits. As a result of monitoring and evaluation, specific feedback is given to faculty members regarding their specific classroom practices. When you go through the literature, a task most commonly associated with educational leadership is that of the audit function. In addition, effective organization in the areas of teaching staff and teaching programs are included. (Hallinger and Murphy, 1987).

The monitoring and evaluation of the educational leader is very important. As a result, the organized is concerned about providing a great contribution. Aydin (1986: 31) stated the purpose of educational supervision, teaching and enhancing the learning process and to make it effective. This task consists of all of the class activities which should focus on the planned and scheduled activities. On the other hand, without such a supervision of a training manager, success would be impossible. Audit application, plans and policy comparison, deviation and identification of errors, time and place; take action, make suggestions, directions, precautions and practices (Taymaz, 1989).

Administrators who want to take part in effective educational institutions must allocate a large portion of the day's program to teaching jobs directly. Monitoring and evaluation is a learning opportunity for a manager. In fact, the university environment creates learning opportunities for all people in this environment. Bath (1980): "An educational institution is a community of learners first of all. Here, administrators, faculty, candidates, students learn the environment... ".

With the educational leader as a teaching resource, the program should work actively in the process of development. Established through dialogue with instructors, teaching them a variety of materials, he should encourage the use of technologies and teaching strategies. At the same time, the manager's most obvious role as instructional leader is to facilitate good teaching. In order to facilitate the training the manager must keep evolving and bring new developments in science and teaching strategies (Pesek, 1985).

Managing the teaching process and the manager's organization of teaching resources, employees feel loyalty to their work, students receive better service and thus the purpose of the organization if fulfilled (Braham, 1996). 
The effectiveness of universities is in a very urgent crisis and this crisis is directly related to leadership in specific fields of applications (Eddy and others, 2005).

This effectiveness brings many benefits to students and the society. These benefits have been listed by Stimson (1996) as follows:

Benefits of the administrator:

- Have a more successful and productive organization,

- Have continuous possibility to improve their skills,

- Take the time to self-improvement.

Benefits of the lecturer:

- Authority to show that they are important,

- Develop education and training skills,

- Have relevancy to the task,

- Gain more independence and responsibility for their work,

- Are ready to accomplish greater value tasks.

Organization benefits:

- Have the willingness and are open to staff development,

- Willing to carry out development.

As a consequence, there is a more effective and high-quality output.

\section{Limitations of the Study}

Some of the research on the subject suggested that managers believe it is the lack of sufficient time to make the desired quality instructional leadership. When examining the results of similar studies there are legal and bureaucratic restrictions that prevent the teaching of the most important factors of leadership, lack of time to devote to instructional issues and conflicting role expectations (Griffin, 1993).

Another even more important factor is the inability of managers' training program and training information (Hallinger and Murphy, 1987). Mcev, (1994) also adds the lack of determination and courage. On the other hand, lack of financial resources, especially for developing countries with scarce resources is an important limitation.

\section{Methodology}

As regards the data collection tool, we used the questtionaire developed by Mehmet Fat "Serve Instructional Leadership Behavior Survey Determining Level of Managers in Universities". The questionnaire is carried out in Aleksander Moisiu University, Ismail Qemali University, Eqerem Cabej University, and a total of 263 faculties responded it.

Mission statement, Managing Teaching and Learning Resources and Creating Positive Climate size scale consist of Cronbach's alpha coefficient. The calculated values are given in Table 1.

The data collected through questionnaires SPSS 11.5 (Statistical Packet for Social Sciences) was transferred to the program. Data were analyzed by frequency, percentage, mean, standard deviation and two-way analysis of variance was calculated. Results $p<.01$ level tested.

Table I: Higher education manager managing the teaching process and being inspiration process of the process

$\begin{array}{lccc}\text { Statement } & \text { N } & \bar{X} & \mathbf{S} \\ \text { 1. Follows the students` academic. development } & 263 & 3,06 & 1,20 \\ \text { 2.Uses the resources efficiently. } & 263 & 3,12 & 1,21 \\ \text { 3.Motivates the academicians that reach the teaching standards. } & 263 & 2,84 & 1,31 \\ \text { 4.Finds the recent research and shares it with the academicians. } & 263 & 3,23 & 1,26 \\ \text { 5.Demonstrates different teaching strategies for different students. } & 263 & 2,85 & 1,28 \\ \text { 6.Keeps records on the performance of the academicians. } & 263 & 3,77 & 1,04 \\ \text { 7.Organises training for developing the aims of the institution. } & 263 & 3,93 & 1,08 \\ \text { 8.Has office hours for students. } & 263 & 4,34 & , 87 \\ \text { 9.Motivates the academicians exchanging experience } & 263 & 3,90 & 1,21 \\ \text { 10.Discusses the evaluation models. } & 263 & 3,87 & 1,13 \\ \text { 11.Makes clear the teaching standarts. } & 263 & 4,02 & , 96 \\ \text { 12.Motivates the academicians to raise their academic quality. } & 263 & 4,06 & , 90\end{array}$


When table I is examined, we see that the universities' managers has office hours for students, they make clear the teaching standarts and motivate the academicians to raise their academic quality. But, at the same time they have problems in motivating the staff to reach the standarts and in demonstrating different teaching strategies for the students.

\section{Results}

Universities 'managers in Albania are in their way to develop standards for becoming leader in teaching and learning process and inspiring the process at the same time.

They have attempts regulated by law, but they have to deal more with international standards of teaching and learning in Albanian universities. They also must collaborate with the academicians to improve the teaching and learning process.

\section{References}

Balci, A. (2001). Etkili Okul ve Okul Geliştirme. Ankara: Pegem Yay. .. (1994). Eğitim Yönetimi. Ankara: Gül Yayınevi.

Bath, R. (1980). Run School Run. Cambridge, Massachusets: Harward University Press.

Braham, B. (1996). Ogrenen Organizasyon Yaratmak. (Cev. A. Tekcan). Istanbul: Rota Yay.

Brookover. W., L. Beamer, D. Hathavey. (1982). Creating Effective Schools: An Inservice Program for Enhancing School Learning Climate and Achievement. Florida: Learning Pub.

Coaldrake, P. (2001). Effective University Structures for the 21st Century. G08 HR Strategies for Innovation and Research. G08 HR/IR Conference, Adelaide.

Deal, T. (1987). Effective School Principals: Counselors, Engineers, Pawnbrakers, Poets or Instructional Leaders. Instructional Leadership: Concepts, Issues and Controversies. Editor: W. Greenfield. Massachusetts: Allyn and Bacon Inc. 231-245.

Gümüşeli, A. (1996). Istanbul İlindeki İlköğretim Okulu Müdürlerinin Öğretim Liderliği Davranışları. Yayınlanmamış Araştırma. Istanbul:Yıldız Teknik Universitesi.

Griffin, M. (1993). Instructional Leadership Behaviours of Catholic Secondar School Principals. Doctoral Dissertation. University of Connecticut.

Hallinger, P., J. Murphy. (1987). Assessing and Developing Principal Instructional Leadership. . İnstructional Leadership: Concepts, Issues and Controversies. Editor: W. Greenfield. Massachusetts: Allyn and Bacon Inc. 179-203.

King, D. (2002). The Changing Shape of Leadership. Educational Leadership. 59, 8. pg. 60 - 66.

Krug, Samuel. (1992). Instructional Leadership, School Instructional Climate and Student Learning Outcomes. Eric Document Reproduction Service. ED359668

Mc. Evan, E. (1994). Seven Steps for Effective Instructional Leadership. New York: Schoolastic Publications.

Paul, J., D. Murphy, D. Spaudling. (1997). 21st Century Practices Needed for Higher Education. Education. Vol. 117, 327-331.

Pesek, R. (1985). The Goals for Higher Education: The University of Toledo as a Case Study. Dissertation Abstracts International. 46 (06). UMI No. 8516746.

Özden, Y. (1998). Eğitimde Dönüşüm. Ankara: Pegem Yayıncılık.

Stimson, N. (1996). Eğitici Önderlik. (Cev. A. Unver). Istanbul: Rota Yayıncılık.

Taymaz, H. (1989). Uygulamalı Okul Yönetimi. Ankara: E.B.F. Yayını.

Wildy, H., C. Dimmock. (1993). Instructional Leadership in Primary and Secondary School in Western Australia. Journal of Educational Administration. 31: 43-61. 